\title{
Millennium exploits retained right with new venture
}

A new wrinkle appeared on the face of genomics with the formation of Millennium BioTherapeutics in May. The new company is a subsidiary of the genomics specialist Millennium Pharmaceuticals (Cambridge, MA), but, following a $\$ 20$ million equity investment, the pharmaceutical company Eli Lilly (Indianapolis, IN) now owns $18 \%$ of the new venture. The real question, though, is what does Lilly get for its money?

Millennium BioTherapeutics fills a commercial gap created by the structure of Millennium Pharmaceuticals' existing deals with large companies, all of which concern the identification of genes (and hence drug development targets) in particular disease areas. The 1995 arrangement with Eli Lilly, for instance, covers genes involved in atherosclerosis and cancer. It has similar alliances with American Home Products (AHP; Madison, NJ) on CNS diseases, Hoffmann-La Roche (Basel, Switzerland) on diabetes and obesity, and Astra (Sodertalje, Sweden) on respiratory diseases. In each of these deals, Millennium Pharmaceuticals has retained the rights to protein and antibody therapeutics, gene therapy, and antisense products (although its rights in the agreement with Roche are restricted to the United States). And Millennium BioTherapeutics is the vehicle for exploiting those rights.

There are obvious concerns about potential conflicts of interest in these arrange ments. Millennium BioTherapeutics is to be assigned the retained rights resulting from Millennium Pharmaceutical's partnerships. Does that mean that Eli Lilly can learndirectly or indirectly-about the genes and targets emerging from the programs that are being funded by Roche, AHP, and Astra? "Simply put," says Christopher Schroll, Millennium BioTherapeutics' director of corporate development and program management, "the contractual agreement between Lilly and Millennium BioTherapeutics ensures that Lilly will not have access to proteins resulting from Millennium's other alliances." Millennium BioTherapeutics and Lilly will each select therapeutic proteins from the pool of those discovered in their collaboration and will develop and commercialize them exclusively. Schroll stresses that Lilly is restricted to those emerging from the new collaboration.
Steven Holtzman, Millennium's chief business officer, says that at least 15 candidate proteins have been identified as high priority so far, and two are already in animal studies. The first initial new drug application is expected in 1999. However, Millenium BioTherapeutics is not planning to take products to market at this stage, he says.

The collaboration "deepens Lilly's ability to discover proteins," says Richard DiMarchi, Lilly's vice president of science/technology. $\mathrm{He}$ expects the agreement to provide a fast route to clinical trials because the mechanisms for protein discovery aspects are already in place at Millennium while Lilly already is strong in development and manufacturing. The alliance "should provide secreted proteins and a number of molecular targets of interest," he says, complementing the combinatorial chemistry capability Lilly acquired when it bought Sphinx in 1994. Lilly's commitment to biological approaches to therapy were further emphasized by its agreement concluded at the end of May with Megabios (Burlington, CA) for the development of a gene-based therapy for some solid tumors.

Emma Dorey

\section{No more mysterious reactions...}

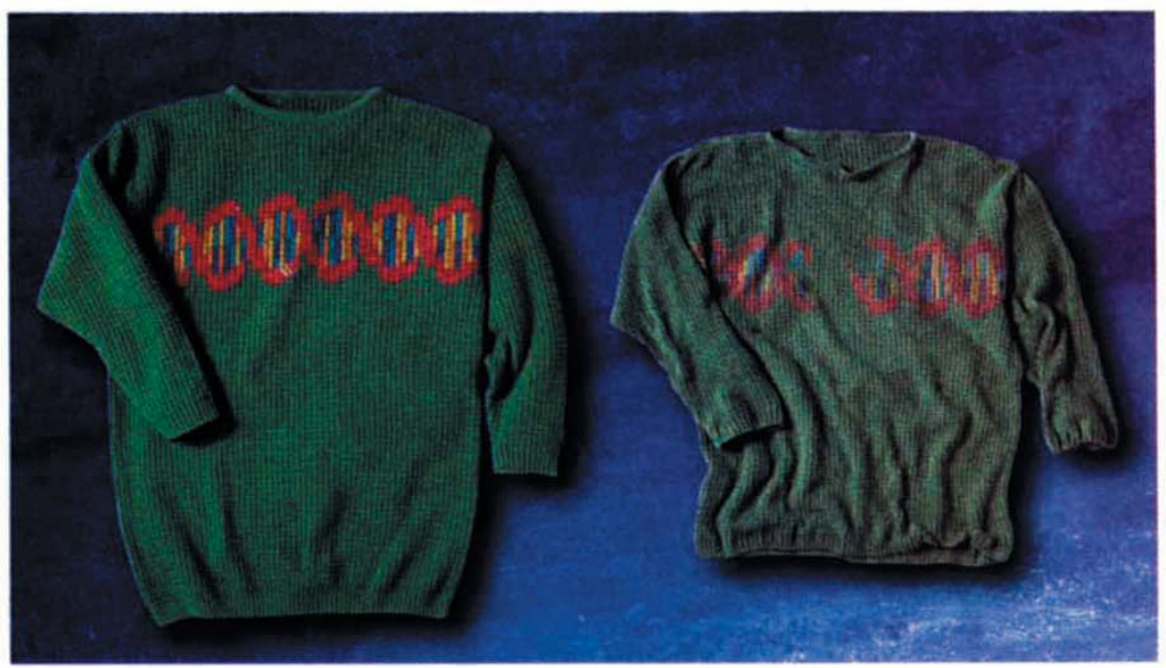

New!

Mastercycler ${ }^{\circ}$ gradient with gradient function Universal block for $96 \times 0.2 \mathrm{ml}$ or $77 \times 0.5 \mathrm{ml}$ tubes or microtiter plates $8 \times 12$

- The gradient function enables building up a temperature gradient of up to $20^{\circ} \mathrm{C}$ across the block

\section{New!}

Mastercycler personal

- Universal block for

$25 \times 0.2 \mathrm{ml}$ or $16 \times 0.5 \mathrm{ml}$ tubes or microtiter plates $5 \times 5$

\section{Mastercycler ${ }^{\infty}$ gradient and Mastercycler}

personal: the new generation of PCR instruments.

- Universal block with excellent temperature homogeneity for either $0.2 \mathrm{ml}$ or $0.5 \mathrm{ml}$ tubes or microtiter plates

- Very fast temperature ramping $\left(\sim 3^{\circ} \mathrm{C} / \mathrm{s}\right)$, heatable lid, flexible software, PC interface and personal memory cards for use with both cyclers and lots more!

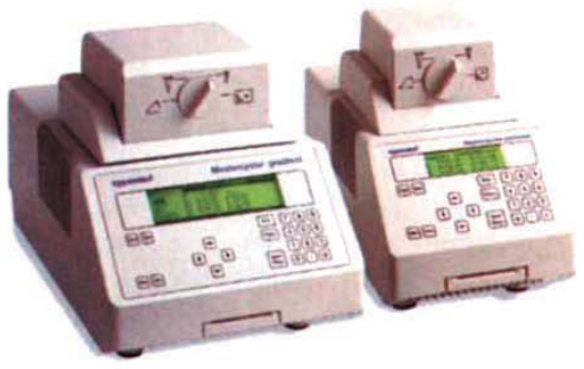

